\title{
Systematics value of micromorphological and palynological characters in Stenocephalum Sch.Bip. (Vernonieae, Asteraceae)
}

\author{
María Betiana ANGULO $^{1,2,}$, Laura CHALUP ${ }^{1}$, Massimiliano DEMATTEIS ${ }^{1,2}$ \\ ${ }^{1}$ Institute of Botany of the Northeast (UNNE-CONICET), Faculty of Agricultural Sciences, Corrientes, Argentina \\ ${ }^{2}$ Faculty of Exact and Natural Sciences and Surveying (UNNE), Corrientes, Argentina
}

Received: $18.12 .2017 \quad \bullet \quad$ Accepted/Published Online: 09.04.2018 • Final Version: 00.00.2018

\begin{abstract}
Micromorphological and palynological characters of all Stenocephalum Sch.Bip. species (Vernonieae, Asteraceae) were analyzed to evaluate their reliability as taxonomic markers at generic level and discussed in relation to other genera of the subtribe Lepidaploinae. Characters such as pubescence of corollas and cypselae showed glandular and nonglandular trichomes allowing differentiation among related species. Apical appendages without glandular trichomes, caudate anthers, and carpopodium structure are common characteristics among Stenocephalum species. With the exceptions of S. megapotamicum and S. tragiaefolium, almost all species of the genus showed style bases without basal nodes for the first time. Crystals on the fruits wall were also observed for the first time in almost all the Stenocephalum species, with the exception of S. hystrix. However, the crystals would not constitute diagnostic features, since they vary widely among species. All the species showed type $\mathrm{C}$ pollen and the genus is considered stenopalynous. However, highly significant differences in palynological features among the species of the genus were observed. The different combinations of the micromorphological and palynological features of Stenocephalum here analyzed are valuable within genera to differentiate related species from one another. The value of all these characters could be increased if they are combined with other morphological or traditional data.
\end{abstract}

Key words: Compositae, micromorphological features, pollen, taxonomy

\section{Introduction}

The tribe Vernonieae Cass. is one of the larger groups of Asteraceae, with about 1700 species distributed in the tropical regions of Asia, Africa, and America (Robinson, 2009). The taxonomic classification of the tribe has changed over time and the huge genus Vernonia Less. ( 1000 species) was suffering divisions, fragmentations, and rearrangements. At present, the tribe is delimited by 21 subtribes with 126 genera, 15 in the New World, and six in the Old World based on morphological, palynological, phytochemical, cytological, and molecular studies (Keeley and Robinson, 2009). Pollen morphology and micromorphological characters (such as style base, apical anther appendages, presence or absence of trichomes on corollas, and crystals on fruit wall) were used as major distinguishing features for subtribal and generic delimitation. The taxonomic revision of American Vernonieae carried out by Robinson (1999) demonstrated the important value of all these features in combination with other characters such as chromosome number, chemical composition, and inflorescence shape. Currently, the subtribe Lepidaploinae is one of the larger groups within the tribe, including 12 genera (Aynia H.Rob., Chrysolaena H.Rob., Harleya S.F.Blake, Echinocoryne H.Rob., Lepidaploa (Cass.) Cass., Lessingianthus H.Rob., Mattfeldanthus H.Rob. \& R.M.King, Pseudopiptocarpha H.Rob., Stenocephalum Sch.Bip., Stilpnopappus Mart. ex DC., Struchium P.Browne, and Xiphochaeta Poepp.), which are grouped by their similar morphological characteristics (inflorescence, pollen morphology, cypselae without pigments, etc.). However, one of the main problems of this group is that many of these general similarities are overlapping characters with shared states or gradual morphologies, which make it difficult to establish relationships among the taxa of the subtribe (Angulo et al., 2015; Via do Pico et al., 2016). Therefore, the search for new morphological data that could help to solve the relationships among genera within the subtribe is constant.

Stenocephalum is one of the genera of Lepidaploinae and it is distributed in South America, mainly in southern Brazil. Since the description of the genus (SchultzBipontinus, 1863), there have been a few problems in its circumscription, but the number of species is variable depending on the author consulted. Robinson (1987)

\footnotetext{
*Correspondence: angulobetiana@gmail.com
} 
considered only five species when resurrecting the genus from synonymy with Vernonia. More recently, Dematteis and Angulo (2008) described a new species for the genus, and Stenocephalum currently includes seven species.

Stenocephalum is characterized by perennial herbs or shrubs with xylopodia, 4-11 florets per capitula, and cylindrical heads grouped in cymose inflorescences (Dematteis and Angulo, 2008). It can be distinguished from other Lepidaploinae genera based on its type C pollen grains, base chromosome number $\mathrm{x}=15$ and 17 , and several micromorphological features, such as the apical anther appendages without glandular trichomes, style base with poorly developed node, and the absence of crystals on the cypsela wall (Jones, 1979; Robinson, 1987, 1999). Although these micromorphological characters are considered diagnostic for the genus, they are only known for some Stenocephalum species. Micromorphological features are also good taxonomic markers in other genera of Lepidaploinae. For example, detailed studies of micromorphological features of Lessingianthus and Chrysolaena showed that the combination of these microcharacters with other macromorphological characters (inflorescence, head shape, phyllaries number) and cytological features are taxonomically useful at specific and generic levels (Angulo and Dematteis, 2014; Angulo et al., 2015; Via do Pico et al., 2016).

Pollen morphology of Stenocephalum has previously been investigated by some authors (Mendonça et al., 2007; Dematteis and Angulo, 2008; Dematteis and Pire, 2008), but they considered only five species of the genus. Pollen type C considered as typical of Stenocephalum is also shared with other related genera of the Lepidaploinae subtribe such as Chrysolaena and some species of Lepidpaloa (Mendonça et al., 2007; Via do Pico and Dematteis, 2013).

Currently, the taxonomic relationships of Stenocephalum with other genera of the subtribe are poorly understood because all species of the genus have not been analyzed from a morphological and palynological point of view and as it was mentioned previously some characters or character states are shared with other closely related to genera of the Lepidaploinae. Therefore, research on new diagnostic features to help clarify the taxonomy in all Stenocephalum species is necessary. When Robinson (1987) segregated the genus, he suggested that Stenocephalum is the closest genus related to the Lepidaploa (Cass.) Cass., sharing some characteristics such as basal stylar node, idioblasts on fruit wall, and pollen type C.

On the other hand, a recent phylogenetic study carried out in the tribe Vernonieae, based on molecular and morphological data, suggested that Stenocephalum is not related to the subtribe Lepidaploinae (Loeuille et al., 2015). However, this study included only one species of Stenocephalum (S. megapotamicum (Spreng.) Sch.Bip.) and a few taxa of Lepidaploinae and wider taxonomic sampling is necessary to achieve a better understanding of the relationships of the subtribe.

Based on this background, we characterize the micromorphological and palynological features of Stenocephalum, in order to establish the value of these characters as diagnostic in all species of the genus and to provide new information in support of current taxonomic classifications proposed for the tribe.

\section{Materials and methods}

Samples of florets, fruits, and pollen grains for each species of Stenocephalum were obtained from natural populations and herbarium specimens (i.e. voucher specimens) from the herbaria CTES, BR, ESA, FCQ, HUEFS, K, MBM, and $\mathrm{W}$ (Thiers, 2017). In order to analyze all the species of the genus, we also included Vernonia hexantha var. nivea Chodat, a taxon considered a variety of Vernonia hexantha (Sch.Bip.) Baker (=S. hexanthum var. hexanthum Sch. Bip.) according to Cabrera and Dematteis (2009). Species and specimens information is detailed in the Appendix.

\subsection{Micromorphological characters}

At least five different florets and cypselae per specimen for micromorphological studies were examined. At least three specimens per species were analyzed depending on material availability. For the observations of floral microcharacters with light microscopy (LM), mature florets were rehydrated and softened in boiling soapy water. For observation of cypsela microcharacters, the mature fruits were treated according to Angulo et al. (2015). Fruits were softened in distilled water for $5 \mathrm{~min}$ and cleared in sodium hypochlorite $50 \%$ until the samples became transparent. Transparent samples were then washed. Both types of samples were dissected under a stereoscopic microscope and then mounted in Hoyer's solution (Anderson, 1954; King and Robinson, 1970; Angulo et al., 2015). Observations were made with a LM equipped with a digital photographic camera (Canon Power Shot A 640).

Observations with a scanning electron microscope (SEM) were performed on live material and herbarium samples. The latter were first rehydrated with warm soapy water and fixed with FAA. Then all samples were first dehydrated and then immersed in $\mathrm{CO}_{2}$ for critical point drying before sputter-coating with gold/palladium. Coated samples were examined and photographed with a SEM (JEOL $5800 \mathrm{LV}$ ).

The chemical identity of the crystals was tested by the acid treatment according to Zarlavsky (2014). Fruits were softened in distilled water for $5 \mathrm{~min}$ and dissected under a stereomicroscope and a few drops of $2 \%$ hydrochloric acid were added. 
For the description of microcharacters, terminology proposed by Metcalfe and Chalk (1979), Narayana (1979), Robinson (1999), and Roque et al. (2009) was used.

\subsection{Pollen grains}

For palynological analysis, pollen grains were obtained from anthers of floret buds of herbarium specimens. Pollen grains were prepared for light microscopy by the acetolysis method according to Erdtman (1960). Then acetolyzed pollen grains were mounted on glass slides using glycerin jelly and subsequently examined with a LM. Permanent preparations were deposited at the Palynological Laboratory of the Universidad Nacional del Nordeste (PAL-CTES). The following pollen measurements were taken for at least 30 grains per sample: polar axis (P), equatorial diameter $(\mathrm{E})$, exine thickness, polar lacuna diameter, spine length, colpus length, and pore diameter. Pollen grains for SEM were first washed in alcohol 96\% and absolute alcohol, then plated with gold/palladium, and examined with SEM. The terminology of Keeley and Jones (1979) and Punt et al. (2007) was used to describe the pollen morphology.

\subsection{Statistical analyses}

A data matrix of eight OTUs (operational taxonomic units) $\times 12$ qualitative variables was constructed. The method used to clustering analysis was unweighted pairgroup (UPGMA). Phenogram distortion was measured by computing the cophenetic correlation coefficient $(r)$. A cluster analysis of the micromorphological characters along with the pollen shape $(\mathrm{P} / \mathrm{E})$ was carried out to examine the similarity among species.

In order to analyze statistically the variation of pollen parameters recorded among species, the averages were compared by multivariate analysis of variance (MANOVA; $\mathrm{P}>0.05$ ) with post hoc Hotelling (Bonferroni) analysis.
The program InfoStat 2013 version was used for both analyses (Di Rienzo et al., 2013).

The complete data matrix used for statistical analysis is available upon request from the senior author.

\section{Results}

Micromorphological and palynological data in all Stenocephalum species are summarized in Tables 1 and 2, respectively. All characters analyzed allowed differentiation among the species of the genus. The micromorphological characters and pollen morphology are shown in Figures 1 and 2 , and 3 and 4 , respectively.

\subsection{Micromorphological characters}

\subsubsection{Trichome morphology}

Glandular and nonglandular trichomes on corolla lobes and cypselae were observed in almost all the species (Figures 1A and 1B). Only in three taxa (S. apiculatum, $S$. monticola, and S. jucundum) were glabrous florets observed (Figures $3 \mathrm{~A}$ and $3 \mathrm{~B}$ ). The three observed trichomes types were classified based on their nonglandular or glandular nature and cellular structure, as follows:

Type I: nonglandular, multicellular, with a terminal cylindrical cell of acute apex longer than the other cells and a foot formed by 1 or 2 basal cells. The side walls are slightly thickened. This trichome type is present on corolla lobes of S. megapotamicum, S. tragiaefolium, S. hexanthum var. hexanthum, and their variety $V$. hexantha var. nivea (Figures 1A and 3C).

Type II (or twin hairs): nonglandular, multicellular, biseriate, and formed by two basal cells and two parallel elongated cells, with slightly thickened and lignified walls (Figure 1G). The two parallel cells vary in length and are separated at the apex. This trichome type is present in all cypselae of Stenocephalum species (Figures 3F and 3G).

Table 1. Micromorphological characters of Stenocephalum.

\begin{tabular}{|c|c|c|c|c|c|c|c|c|c|c|c|c|c|c|c|c|}
\hline \multirow[t]{2}{*}{ Species } & \multicolumn{3}{|c|}{ Corolla pubescence } & \multicolumn{3}{|c|}{ Apical anther appendage } & \multicolumn{2}{|c|}{ Style base } & \multirow{2}{*}{$\begin{array}{l}\text { Fruit size in mm } \\
\text { (without papus) }\end{array}$} & \multicolumn{2}{|c|}{ Fruit pubescence } & \multicolumn{2}{|c|}{ Idioblasts } & \multicolumn{3}{|c|}{ Crystals } \\
\hline & 1 & 2 & 3 & 1 & 2 & size $(\mathrm{mm})$ & 1 & 2 & & 1 & 2 & 1 & 2 & 1 & 2 & 3 \\
\hline S. apiculatum & $\mathrm{x}$ & & & $\mathrm{x}$ & & $0.3-0.4$ & $\mathrm{x}$ & & $3.0-3.5$ & $\mathrm{x}$ & $\mathrm{x}$ & $\mathrm{x}$ & & $\mathrm{x}$ & & \\
\hline S. hexanthum var. hexanthum & & $\mathrm{x}$ & $\mathrm{x}$ & & $\mathrm{x}$ & $0.5-0.6$ & $\mathrm{x}$ & & $2.5-3.0$ & $\mathrm{x}$ & & $\mathrm{x}$ & & & & $\mathrm{x}$ \\
\hline S. hystrix & & & $\mathrm{x}$ & $\mathrm{x}$ & & $0.3-0.4$ & $\mathrm{x}$ & & $3.0-3.3$ & $\mathrm{x}$ & & & $\mathrm{x}$ & & $\mathrm{x}$ & \\
\hline S. jucundum & $\mathrm{x}$ & & & & $\mathrm{x}$ & $0.3-0.4$ & $\mathrm{x}$ & & $3.0-4.5$ & $\mathrm{x}$ & & $\mathrm{x}$ & & $\mathrm{x}$ & & \\
\hline S. megapotamicum & & $\mathrm{x}$ & & $\mathrm{x}$ & & $0.3-0.4$ & & $\mathrm{x}$ & $2.5-2.6$ & $\mathrm{x}$ & & & $\mathrm{x}$ & $\mathrm{x}$ & & \\
\hline S. monticola & $\mathrm{x}$ & & & $\mathrm{x}$ & & $0.3-0.4$ & $\mathrm{x}$ & & $2.5-3.0$ & $\mathrm{x}$ & & $\mathrm{x}$ & & $\mathrm{x}$ & & \\
\hline S. tragiaefolium & & $\mathrm{x}$ & & $\mathrm{x}$ & & $0.3-0.4$ & & $\mathrm{x}$ & $2.5-3.0$ & $\mathrm{x}$ & & & $\mathrm{x}$ & & $\mathrm{x}$ & \\
\hline$V$. hexantha var. nivea * & & $\mathrm{x}$ & $\mathrm{x}$ & $\mathrm{x}$ & & $0.4-0.5$ & $\mathrm{x}$ & & $2.5-3.0$ & $\mathrm{x}$ & & & $\mathrm{x}$ & $\mathrm{x}$ & & \\
\hline
\end{tabular}

Corolla pubescence: 1: glabrous; 2: nonglandular trichomes; 3: glandular trichomes. Anther apical appendages: 1: lanceolate; 2: ovate-lanceolate. Style base: 1: without basal node; 2: with poorly developed basal node. Fruit pubescence: 1 : nonglandular trichomes, 2: glandular trichomes. Idioblasts: 1 : present; 2 : absent. Crystals: 1 : present; 2 : absent; 3: present/absent. ${ }^{*} V$. hexantha var. nivea is a variety of $V$. hexantha (= S. hexanthum var. hexanthum). 
ANGULO et al. / Turk J Bot

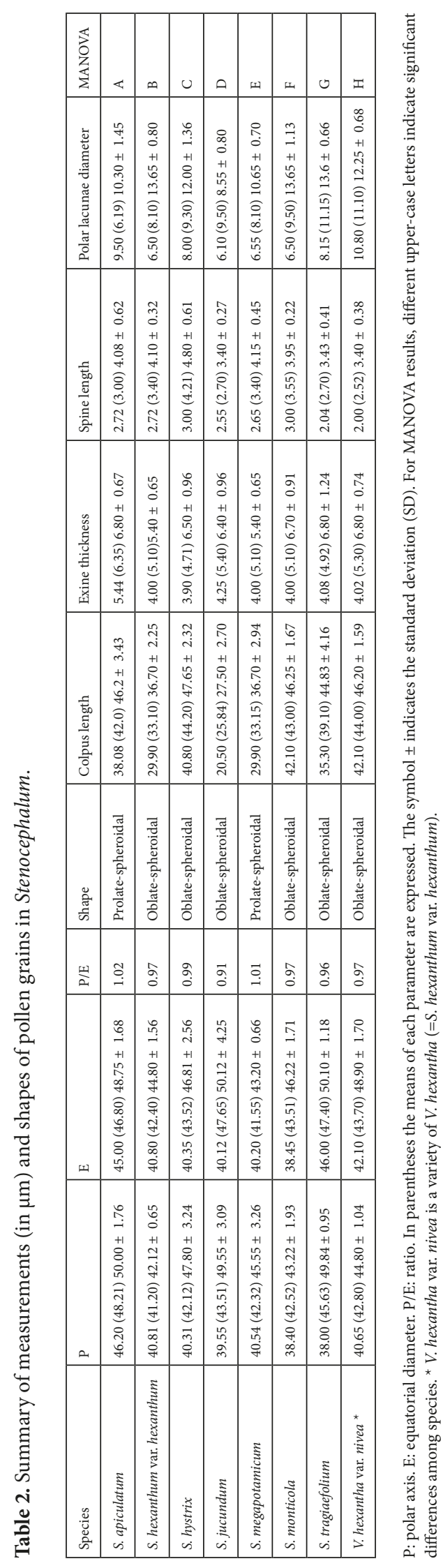



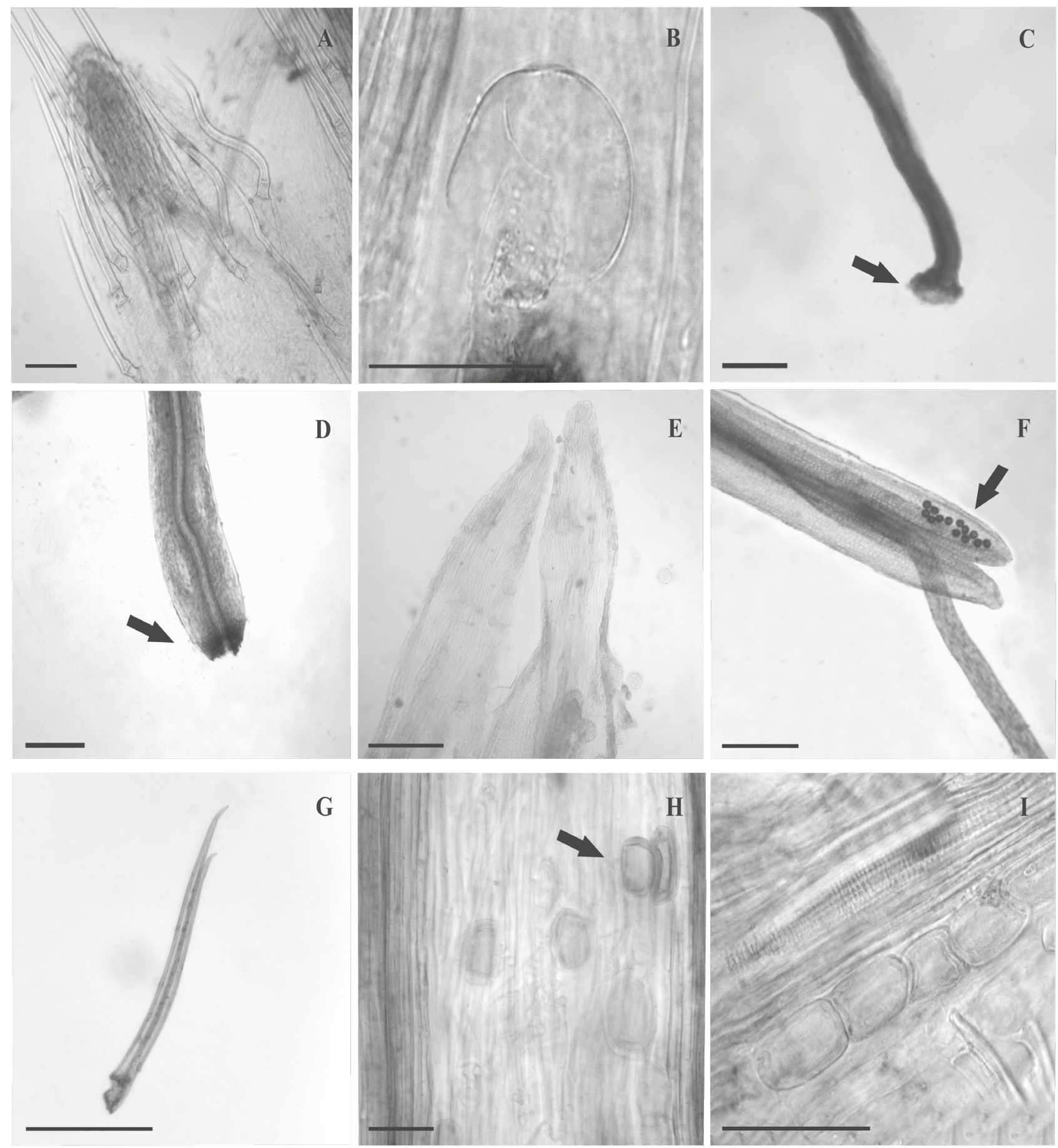

Figure 1. Micromorphological characters in Stenocephalum (LM). A: Corolla lobe with nonglandular trichomes of S. megapotamicum. B: Trichome glandular type III of S. hystrix. C: Style base showing a little developed node of S. tragiaefolium (arrow). D: Style base without basal node (arrow) of S. jucundum. E-F: S. tragiaefolium, E: Lanceolate apical anther appendage without glandular trichomes, F: Calcarate anther base showing the thecae extending below the point where the filament connects with the anther (arrow). G: Twin hair of S. monticola. H: Detail of cypsela showing solitary idioblasts (arrow) of S. apiculatum. I: Fruit detail showing groups up to five idioblasts of $S$. hexanthum var. hexanthum. Scale bars: $50 \mu \mathrm{m}$ (A, C-F, H), $100 \mu \mathrm{m}$ (B, G, I). 

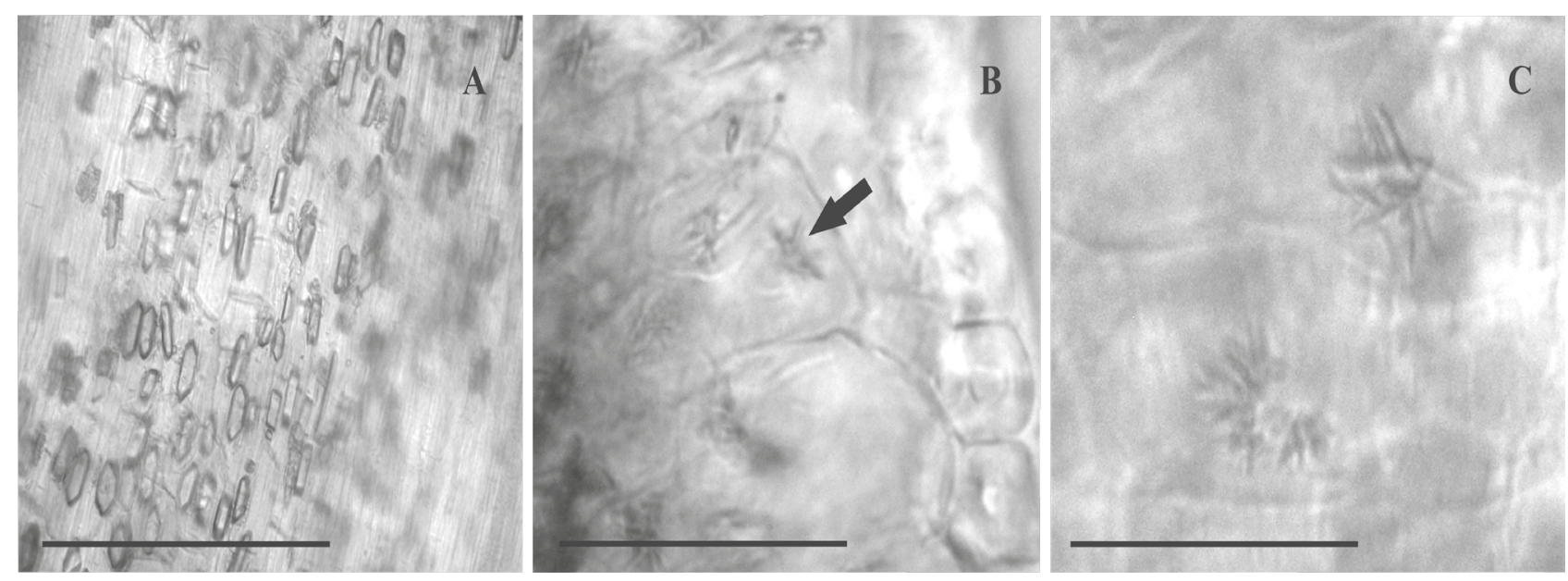

Figure 2. Crystals of Stenocephalum species (LM). A: Prismatic crystals of S. jucundum. B-C: S. monticola, B: Detail of fruit base showing druses (arrow), C: Druses. Scale bar: $100 \mu \mathrm{m}$.

Type III: glandular, multicelullar, with a uniseriate foot formed by 1 or 2 cells and unicellular head. This may persist or collapse. The cell walls are thin. This trichome type was only observed on corolla lobes of S. hystrix, S. hexanthum var. hexanthum, and $V$. hexantha var. nivea (Figures 1B, 3C, and 3D), and also on cypselae of S. apiculatum (Figure $2 \mathrm{G})$.

Trichomes types I and III are always located on the dorsal side of corolla lobes. Stenocephalum megapotamicum and $S$. tragiaefolium exclusively have trichomes type I, while $S$. hystrix exclusively has trichomes type III. Stenocephalum hexanthum var. hexanthum and their variety $V$. hexantha var. nivea have both trichomes types on corolla lobes.

\subsubsection{Styles}

The styles of Stenocephalum species are of vernonioid type, which is bifid, slender, with sweeping hairs along the branches as well as on the upper part of the shaft. The inner part of the branches of the style is covered with stigmatic papillae and is glabrous to subglabrous towards the base, while nonglandular trichomes (unicellular and subulate) are distributed from the middle part to the apex (Figure 3E).

Stenocephalum megapotamicum and S. tragiaefolium have a poorly developed node just above the nectary formed by a few rows of cells of thick-walled cells (Figure 1C), whereas the remaining species have styles without basal nodes (Figure 1D).

\subsubsection{Base of anther thecae and apical appendage}

The apical appendages of anthers are flat with different shapes: lanceolate and ovate-lanceolate. Their sizes range from $0.3 \mathrm{~mm}$ long in $S$. jucundum to $0.6 \mathrm{~mm}$ long in $S$. hexanthum var. hexanthum. All species have nonglandular appendages (Figure 1E).
Anther thecae bases of all the species are sagittate and calcarate (Figure 1F) with thecae extending below the point where the filament connects with the anther.

\subsubsection{Cypselae}

Cypselae of Stenocephalum are cylindrical or cylindricalobconical and their length varies from 2.3 to $5.3 \mathrm{~mm}$ long (see Table 1). The pappus is whitish or yellowish, biseriate, with an outer series of short paleaceous setae $(0.5-2 \mathrm{~mm})$, fimbriate, lanceolate and an inner series with long cylindrical bristles (4.5-12 $\mathrm{mm}$ ) (Figure 3F). All the species have very similar indumentum with trichomes type I (twin hairs) distributed throughout the surface of the fruit (Figure 3F). Only S. apiculatum has also a few glandular trichomes type III located mainly at the fruit base (Figure 3G). Besides trichomes, some species have cypselae with idioblasts (see Table 1), which are difficult to observe due to the abundance of twin hairs. Idioblasts are larger than the other cells of uniseriate epidermis and they are more or less ellipsoidal or rounded structures with thickened and lignified walls (Figures $1 \mathrm{H}$ and $3 \mathrm{H}$ ). These cells are distributed irregularity over the fruit, scattered or longitudinally arranged forming groups of 2 to 5 cells (Figure 1I). Stenocephalum hystrix, S. megapotamicum, S. tragiaefolium, and $V$. hexantha var. nivea lack idioblasts.

\subsubsection{Carpopodium}

The carpopodium is the scar of the abscission zone on the cypsela base formed by one or more rows of cells that usually are morphologically distinct from other cells of the fruit wall. All the examined species show a well differentiated carpopodium as a complete ring formed by several rows of quadrate and subquadrate cells with thickened walls (Figure 3G). 

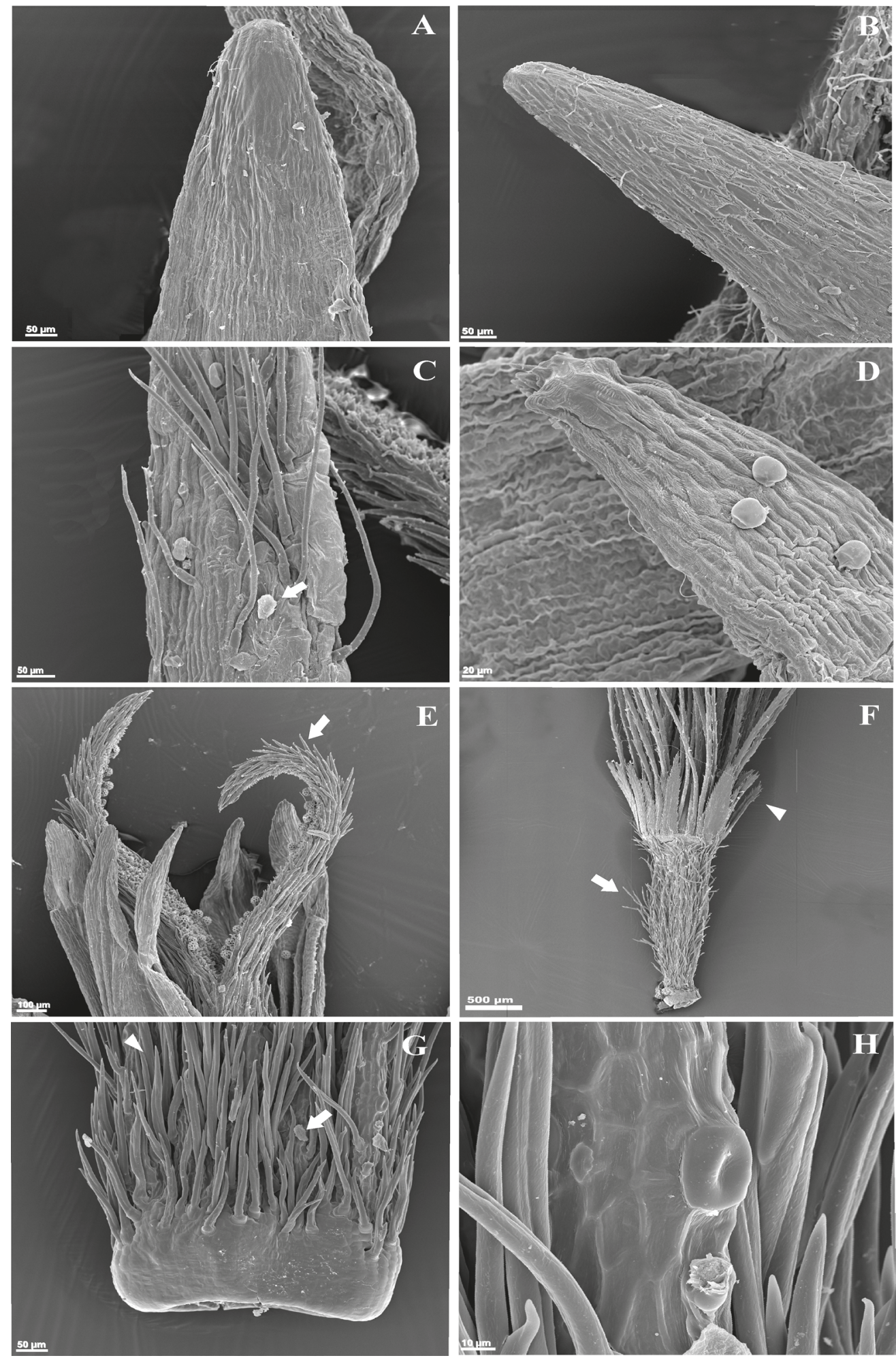

Figure 3. Micromorphological characters in Stenocephalum (SEM). A: Glabrous corolla lobe of S. jucundum. B: Glabrous corolla lobe of S. monticola. C: Corolla lobe with nonglandular trichomes and glandular trichomes (arrow) of S. hexanthum var. hexanthum. D-E: S. hystirx, D: Corolla lobe showing glandular trichomes, E: Style branches showing nonglandular trichomes (arrow). F-H: Cypsela of S. apiculatum, F: General view of cypsela showing pappus (arrowhead) and twin hairs (arrow) distributed throughout the surface of the fruit, G: Cypsela base showing carpopodium and nonglandular trichomes (arrowhead) and glandular trichomes (arrow), H: Detail of the fruit showing idioblast. Scale bars: $10 \mu \mathrm{m}(\mathrm{H}), 20 \mu \mathrm{m}(\mathrm{D}), 50 \mu \mathrm{m}(\mathrm{A}-\mathrm{C}, \mathrm{G}), 100 \mu \mathrm{m}$ (E), $500 \mu \mathrm{m}(\mathrm{F})$. 

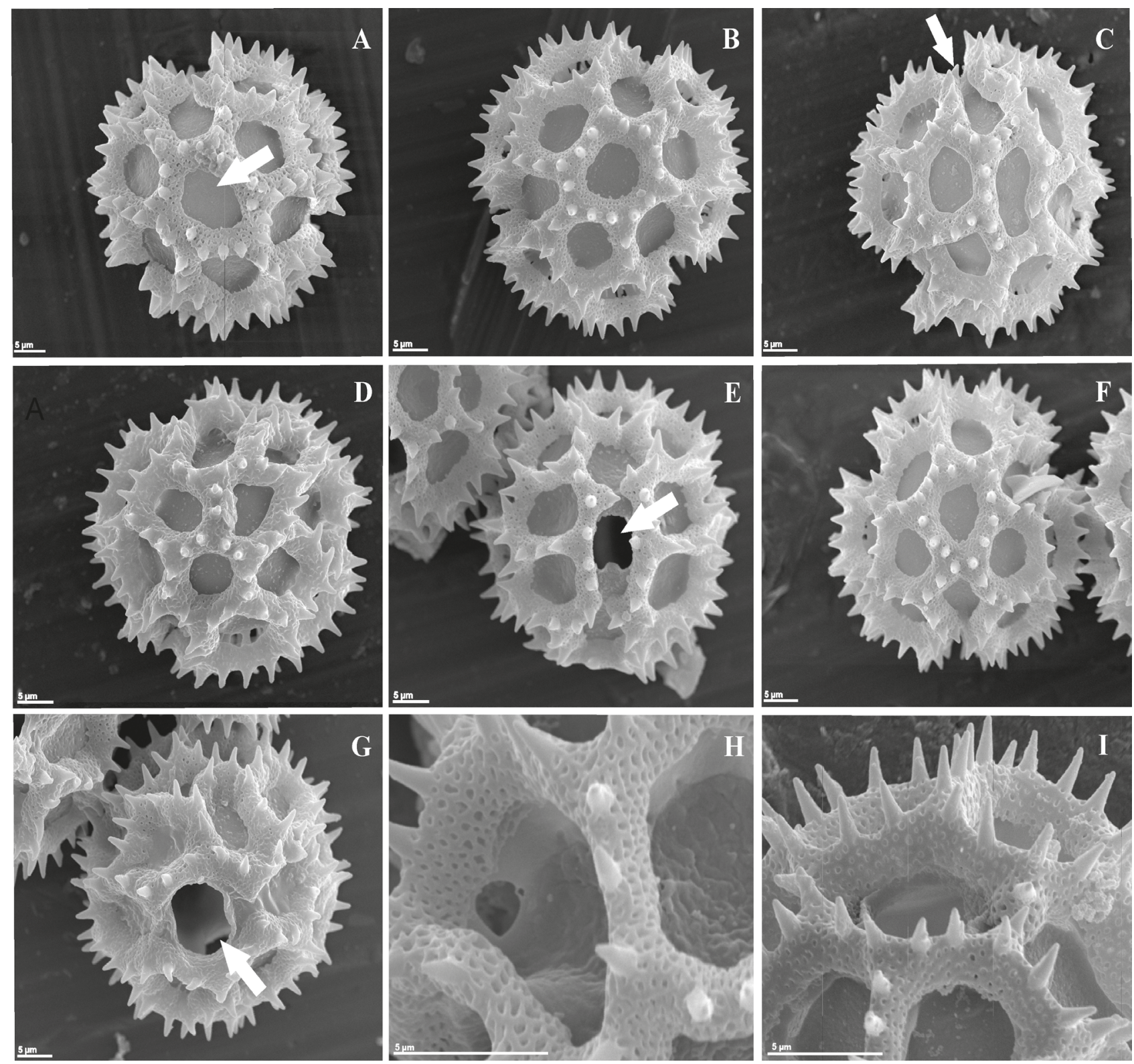

Figure 4. Pollen grains of the studied taxa (SEM). A: Polar view showing polar lacuna (arrow) of S. apiculatum. B: Polar view showing polar lacuna of S. hexanthum var. hexanthum. C-D: V. hexantha var. nivea. C: Polar view, showing the colpi (arrow). D: Equatorial view, mesocolpium. E: Equatorial view showing pori (arrow) of S. hystrix. F-G: S. jucundum, F: Polar view, G: Equatorial view, pori (arrow). H: Detail of tectum microperforate of $S$. megapotamicum. I: Detail of spinae of S. tragiaefolium. Scale bar: $5 \mu \mathrm{m}$.

\subsubsection{Crystals in the pericarp}

Almost all species of Stenocephalum have crystals in the pericarp, which are composed by calcium oxalate $(\mathrm{CaOx})$ as they dissolved with $2 \%$ hydrochloric acid (without producing bubbles).

Crystals have different shapes: prismatic, cubic, and druses (Figures 2A-2C), which are variable in size and density among the specimens. The prismatic crystals are the most common among the species studied (Figure $2 \mathrm{~A})$. These are rectangular or hexagonal in surface view and they are distributed through the whole fruit wall. The druses, however, are located at the carpopodium and were only observed in $S$. hexanthum var. hexanthum and $S$. monticola (Figures 2B and 2C). Nevertheless, not all the specimens analyzed of $S$. hexanthum var. hexanthum have crystals on the fruit wall.

\subsection{General pollen morphology}

The pollen morphology of $S$. jucundum, S. hexanthum var. hexanthum, and $V$. hexantha var. nivea was analyzed here for the first time. All Stenocephalum species have 
type C pollen grains (Figures 4A-4I). These pollen grains were radially symmetric, prolate-spheroidal, and oblate-spheroidal (P/E, from 0.91 to 1.02), 3-colporate, echinolophate. Values of $\mathrm{P}$ ranged between 41.20 and $48.20 \mu \mathrm{m}$, and the values of E between 41.50 and $47.60 \mu \mathrm{m}$. Exine thicknesses, excluding spines, ranged between 4.71 to $6.35 \mu \mathrm{m}$ thick, with the sexine thicker than the nexine. Lacunae are surrounded by lophae and are more or less regular in outline. There are 29 lacunae in total: 3 poral, 6 abporal, 12 paraporal, 6 interpolar, and 2 polar. Polar lacunae measured between 6.19 and $11.15 \mu \mathrm{m}$, and have a variable shape: more or less circular, triangular or slightly pentagonal (Figures $4 \mathrm{~A}-4 \mathrm{C}$ ). The colpi are visible in polar view (Figure 4C) and relatively long, measuring from 25.84 to $44.20 \mu \mathrm{m}$. They interrupt the lophae that separate the poral lacuna from the abporal lacunae. The pori are circular and lolongate (Figure 4E) in most species, and lalongate in S. apiculatum, S. jucundum (Figure 4G), and S. tragiaefolium. The tectum was discontinuous and densely microperforate (Figure $4 \mathrm{H}$ ) with acute spines (Figure 4I) arranged in a linear distribution along the ridges of the lophae; the spine length varies from 2.52 to $4.21 \mu \mathrm{m}$.

\subsection{Statistical analysis}

The UPGMA dendrogram (Figure 5) constructed on the basis of microcharacters and the pollen shape $(\mathrm{P} / \mathrm{E})$ shows that the species are divided in two groups based on the presence or absence of basal stylar node. Group 1 (G-1) includes species with a node at the style base, while in Group 2 (G-2) are all other taxa without a node.
Group 2 is subdivided in two: subgroup 2A (SG-2A) with species with glabrous corollas and subgroup 2B (SG-2B) contains species with glandular trichomes on corolla lobes. Subgroup 2A is divided, again, into two groups (SG2 AA and SG-2 Aa) based on the presence of glandular trichomes on cypsela and pollen shape. On the other hand, subgroup $2 \mathrm{~B}$ is also divided into two groups (SG-2 BB and SG-2 Bb) based on apical anther shape and the presence or absence of idioblasts.

In addition, the MANOVA analysis carried out considering all pollen variables showed significant differences $(\lambda=5.75 ; \mathrm{F}=190.62 ; \mathrm{P}<0.0001)$ among the species analyzed, and the Bonferroni analysis displayed significant differences for all species (Table 2).

\section{Discussion}

The results of this study showed some of the micromorphological characters such as apical anther appendages without glandular trichomes, calcarate and caudate anthers, papillae on the style, biseriate pappus, carpopodium structure, and the pollen type are common characteristics among Stenocephalum species. However, we observed several different microcharacters (corolla and cypsela pubescence, presence or absence of idioblasts, etc.) and certain characteristics of pollen morphology ( $\mathrm{P}$ and $\mathrm{E}$ values, shape, polar lacunae diameter, etc.) with important diagnostic value for Stenocephalum at generic and infrageneric levels. We discussed separately the microcharacters and pollen features examined.



Figure 5. Dendrogram showing the phenetic relationships among the studied species of Stenocephalum, constructed using the matrix of micromorphological and palynological similarities with UPGMA. Cophenetic correlation $r=0.89$. G: group, SG: subgroup, (I): presence of basal stylar node, (I'): absence of basal stylar node, (II): glabrous corollas, (II'): corollas with glandular trichomes, (III): absence of glandular trichomes on fruits, (III'): presence of glandular trichomes on fruits, (IV): pollen prolate, (IV'): pollen oblate, (V): presence of idioblasts, ( $\left.\mathrm{V}^{\prime}\right)$ : absence of idioblasts, (VI): apical appendages oval-lanceolate, apical appendages oval-lanceolate, (VI'): apical appendages lanceolate. 


\subsection{Micromorphological characters}

This study represents the first comprehensive survey of the micromorphological characters used by Robinson (1987) for the circumscription of Stenocephalum. In addition, other microcharacters of taxonomic significance were analyzed in all species of the genus.

Trichome types are one of the microcharacters that show a great variation within Asteraceae, being glandular and nonglandular with variations in structure, distribution, and number of cells (Metcalfe and Chalk, 1979; Narayana, 1979; Robinson, 2009). They occur in reproductive and vegetative organs including root systems (Isawumi et al., 1996; Appezzato-da-Glória et al., 2012). In Stenocephalum, a total of three trichomes types (I, II, and III) were described based on their glandular and nonglandular nature and the number and organization of their cells. These trichome types were consistent with those described for other Lepidaploinae. For example, the morphology of nonglandular trichomes designed here as type I and II agrees with the morphology of trichomes described for Lessingianthus (Angulo and Dematteis, 2014) and Chrysolaena (Via do Pico et al., 2016). Regarding the glandular trichomes (type III) of Stenocephalum, their morphology is also similar to that of the glandular trichomes of corollas of Lessingianthus (type III) and Chrysolaena (type III A) (Angulo and Dematteis, 2014; Via do Pico et al., 2016). In the present study, only a few Stenocephalum species showed glandular trichomes on corolla lobes. Previous studies carried out in other taxa of the tribe Vernonieae established the great importance of trichomes for comparative systematic studies, showing that their presence or absence can be used to differentiate closely related species and genera within the tribe (Faust and Jones, 1973; Wagner et al., 2014). In Stenocephalum, the trichomes also allowed to differentiate some species. Stenocephalum apiculatum, S. jucundum, and S. monticola have corollas without trichomes, this characteristic being constant in these taxa, while the remaining entities have some kind of trichomes on corolla lobes. Moreover, the trichomes of cypselae presented diagnostic value at species level. Robinson (1999) proposed that the fruits of Stenocephalum had only nonglandular trichomes (twin hairs). However, we observed glandular trichomes on cypselae of $S$. apiculatum, being the only species of the genus with this characteristic on the fruits.

On the other hand, the general morphology of styles (type vernonoid) of Stenocephalum agrees with the styles observed in almost all Lepidpaloinae and it was a useful taxonomic character at generic level. As regards the style base, the presence of a poorly differentiated node is considered a distinctive character of Stenocephalum species (Robinson, 1999). Nevertheless, we observed for the first time that the majority of the species lacked a node and only in S. megapotamicum and S. tragiaefolium was a narrow basal ring observed. The presence or absence of a basal stylar node was one of the features used in Vernonieae's classification (Robinson, 1988). Almost all genera of Lepidaploinae have styles with basal nodes (Robinson, 1999), but our results do not fit with the proposal by this author.

Variations of base of anther thecae and apical appendages have been considered very important in Asteraceae classification (Bremer, 1994). Robinson (1999) also considered these microcharacters in his taxonomic treatment of American Vernonieae. Stenocephalum has calcarate and caudate anthers with sagittate shape, and apical anther appendage without glandular trichomes, coinciding with almost all species of Lepidaploinae, with the only exception being $X$. aquatica Poepp. with anther bases ecalcarate with anther spurs shorter than anther collar (Robinson, 1999). Stuessy et al. (1996) suggested that apical appendages would be an adaptation to protect the pollen from humidity and insect predators, until the stigma and style push it up for pollen presentation. Recently, Erbar and Leins (2015) proposed the same function for the cuticular striation observed on the stylar hairs. Therefore, anther structures and the cuticular striation of the stylar hairs would seem to be related to the increase in the repellence of water drops in the florets.

Several systematics studies in Asteraceae have emphasized the utility of fruit features (indumentum, pappus, carpopodium structure, crystals in epidermal cells, and the anatomy of the pericarp or a combination of all of these characters) to delimitate tribes, genera, and even species within this family (Haque and Godward, 1984; Freitas et al., 2015). Stenocephalum species are uniform in the indumentum type, pappus features, and carpopodium structure, being good taxonomic markers at generic level.

Almost all species of Stenocephalum have idioblasts in the cypsela wall; therefore, they have diagnostic value at an infrageneric level. This feature can be used to differentiate closely related species, for example S. monticola (with idioblasts) from S. tragiaefolium (without idioblasts). From a histological point of view, idioblasts are isolated cells that differ in shape, size, content, and structure of the wall elements regarding surrounding tissue (Foster, 1955). Several authors do not agree about the concept of these structures; for example, Hind (1993) considered these structures as glands, while Robinson (1999) described them as idioblasts. Recently, Angulo et al. (2015) carried out anatomical studies on fruits of Lessingianthus and they observed that these cells are certainly idioblasts (ellipsoidal or rounded cells with very dense cytoplasm, evident nucleus, and remarkably thickened and lignified walls), which are very similar in structure and disposition to those observed on cypselae of Stenocephalum. The 
cellular content of idioblasts and their function remain unknown (Isawumi, 1999; Angulo et al., 2015; Via do Pico et al., 2016). Mazen et al. (2004) related the process of $\mathrm{CaOx}$ crystal formation with cells called crystal idioblasts. However, Stenocephalum species without idioblasts (S. megapotamicum, and $V$. hexantha var. nivea) showed crystals in the fruit pericarp; therefore their presence would not be related to the crystal formation process.

The taxonomic significance of the crystals of the pericarp has been studied in several tribes of Asteraceae (Dormer, 1961; Isawumi et al., 1996). Robinson (1999) highlighted the taxonomic value of the different crystal shapes, as well as their presence or absence to differentiate American Vernonieae. The lack of crystals in the pericarp of Stenocephalum was one the features that Robinson (1987) used in the segregation of the genus. Instead, we observed crystals (prismatic, cubic, and druses) in Stenocephalum fruits for the first time, which were variable in size and density among the specimens. Prismatic crystals were the most frequent in all analyzed species, being druses observed only in carpopodium of S. hexanthum var. hexanthum and S. monticola. Robinson (1999) suggested elongate crystals (the correct term would be cubic because it is a tridimensional structure) for almost all genera of Lepidaploinae (Struchium, Echinocoryne, Xyphochaeta, Chrysolaena, Mattfeldanthus, and Lepidaploa), while square (the correct term would be prismatic) crystals were proposed for Stilpnopappus, Aynia, Pseudopiptocarpha, Harleya, and Lessingianthus. However, recent studies carried out in Lessingianthus (Angulo et al., 2015) and Chrysolaena (Via do Pico et al., 2016) demonstrated that crystals have variable shapes: cubic, prismatic, styloid, and druses. In this sense, the crystal shape of cypselae is not a good diagnostic character at generic level because the states of this character overlap in most Vernonieae genera. As regards the Stenocephalum, the morphology and the presence of crystals are not constant within species and so they would not be taxonomically useful characters to recognize species.

\subsection{Pollen grain morphology}

Pollen morphology was one of most important characters in Stenocephalum delimitation (Robinson, 1987). In this study, we show that all the species of the genus have pollen grains with a lophate pattern comparable with the Vernonia cognata type (Stix, 1960), also designated as type C by Keeley and Jones (1979). Therefore, our results support the conclusion by Robinson (1987) that the type C pollen characterizes the whole group and Stenocephalum is thus considered a stenopalynous genus. We describe the detailed morphology of pollen in all Stenocephalum species. Our findings agree with the results of previous analysis about S. monticola (Dematteis and Angulo, 2008) and S. hystrix (Dematteis and Pire, 2008), and with reports by Mendonça et al. (2007) of S. apiculatum, S. megapotamicum, and S. tragiaefolium.

Although all species are palynologically similar (pollen type and number of apertures), some differences were observed. For example, they differ in grain shape (prolate-spheroidal vs. oblate-spheroidal), grain size, exine thickness, spine length, and polar lacuna diameter. Several authors used the quantitative traits of pollen grains to elaborate taxonomic keys (Mendonça et al., 2007; Via do Pico and Dematteis, 2013). In Stenocephalum, all the differences mentioned above were significant at infrageneric level according to MANOVA results. The set of different quantitative characters taken to define the pollen grains allowed us to differentiate each one of the Stenocephalum species. Despite the controversies cited in the literature in which some authors propose to define $V$. hexantha var. hexantha and $V$. hexantha var. nivea as synonyms of S. megapotamicum (Robinson, 1999) and other authors consider them as good species (Dematteis and Angulo, 2008; Cabrera and Dematteis, 2009), our analysis allowed us to identify them as distinct entities. It is clear that, taken together, these parameters could be used as an additional good tool to separate species.

The high variation in pollen morphology (aperture and surface) proves to be useful in delimiting natural groups in the Vernonieae. Currently, 10 pollen types (from A to J) are recognized for the tribe (Keeley and Jones, 1979; Robinson, 1992). Several authors showed some variations of these pollen types but all these studies demonstrated that these pollen types are very good diagnostic characters at generic level (Mendonça et al., 2007; Dematteis and Pire, 2008; Angulo and Dematteis, 2010; Via do Pico and Dematteis, 2013). In the subtribe Lepidaploinae, some of these pollen types (A-D, G, J and pollen Aynia) are shared by various genera. For example, the type $\mathrm{C}$ pollen characteristic of Stenocephalum is also present in other genera of the subtribe such as Chrysolaena and in some species of Lepidaploa (Robinson, 1999); however, these genera differ in other several conspicuous morphological features such us inflorescence type, head size, floret and phyllary number Despite the overlap of pollen types within Lepidaploinae subtribe, pollen is a very important and useful character at generic level when it combined with other diagnostic features and it is routinely included in the basic descriptions of genera. Our results confirm that palynological data was also useful in Stenocephalum and it constitutes a well-defined group based on its pollen features.

Phylogenetic analyses based on molecular and morphological data (Loeuille et al., 2015) have indicated that $S$. megapotamicum is placed outside the subtribe Lepidaploinae and it is closely related to Rolandra fruticosa (L.) Kuntze (Rolandriane subtribe). These 
authors suggested that both taxa are similar in some morphological features such as in the reduced number of phyllaries and florets. If we considered the palynological features of both taxa, we observed that they are very different. Rolandra fruticosa has type F pollen, which is triporate and multiareolate (complete surface covered with lacunae of similar size including three that contain the pores) (Robinson, 1992, 1999), which is very different from type C observed in Stenocephalum; in addition type F pollen is not represented in Lepidaploinae. Probably, this relationship could be due to the fact that not all the species of Stenocephalum and a few Lepidapaloinae taxa were represented.

In conclusion, all palynological and almost all micromorphological characters have diagnostic value for Stenocephalum species. In addition, the statistical analyses carried out in this study showed the importance of these features for grouping species.

On the other hand, the homogeneity of type C observed in all Stenocephalum demonstrated that the pollen type constitutes a good taxonomic marker at generic level and the combination of quantitative pollen traits also allowed separating species. Several micromorphological characters (apical appendages without glandular trichomes, caudate anthers, and carpopodium structure) also had diagnostic value at generic level. Characters such as style base with or without basal node, the pubescence of corollas and cypselae, and the presence or absence of idioblasts allowed differentiating among related species. Crystals were the only microcharacter highly variable among species and populations of the same species, and so

\section{References}

Anderson LE (1954). Hoyer's solution as a rapid mounting medium for bryophytes. The Bryologist 57: 242-247.

Angulo MB, Dematteis M (2010). Pollen morphology of the South American genus Lessingianthus (Vernonieae, Asteraceae) and its taxonomic implications. Grana 49: 12-25.

Angulo MB, Dematteis M (2014). Floral microcharacters in Lessingianthus (Vernonieae, Asteraceae) and their taxonomic implications. Plant Syst Evol 300: 1925-1940.

Angulo MB, Sosa MM, Dematteis M (2015). Systematic significance of cypsela morphology in Lessingianthus (Vernonieae, Asteraceae). Aust Syst Bot 28: 173-189.

Appezzato-da-Glória B, Da Costa FB, da Silva VC, Gobbo-Neto L, Garcia Rehder VL, Hayashi AH (2012). Glandular trichomes on aerial and underground organs in Chrysolaena species (Vernonieae-Asteraceae): Structure, ultrastructure and chemical composition. Flora 207: 878-889.

Bremer K (1994). Asteraceae: Cladistics and Classification. 1st ed. Portland, OR, USA: Timber Press. these would not be a useful character for the systematics of the genus. However, if we consider their presence or absence in combination with other features, their value as a taxonomic criterion at specific level could be increased. In $S$. hexanthum var. hexanthum, although not all the specimens analyzed showed crystals on fruits, this is one of the features in combination with other characters that allowed us to separate this taxon from $V$. hexantha var. nivea without crystals. This character along with other characters such as the shape of apical appendages of anthers, the presence or absence of idioblasts, and the size of pollen grains differentiates both taxa. All these features in combination with other macrocharacters such as inflorescence type and leaf and phyllary shape are distinctive for both taxa. In consequence, these taxa could be regarded as different species. Therefore, this is a clear example that micromorphological and palynological characters here analyzed are valuable to differentiate species within Stenocephalum and their value as taxonomic criterion could be increased if combined with other lines of evidence such as macromorphological or traditional characters.

\section{Acknowledgments}

We are grateful for the financial support provided by the Secretaría General de Ciencia y Técnica de la Universidad Nacional del Nordeste, the Consejo Nacional de Investigaciones Científicas y Técnicas and the Agencia Nacional de Promoción Científica y Tecnológica (PI No. 15-P002, PIP No. 11220150100125, PICT No. 2015-2804, PICT No. 2016-2686).

Cabrera AL, Dematteis M (2009). Compositae. IV. Asteroideae. In Ramella R, Perret P editors. Flora del Paraguay. Geneva, Switzerland: Conservatoire et Jardin botaniques de Genève \& Missouri Botanical Garden, pp. 65-267.

Dematteis M, Angulo MB (2008). Taxonomic Position and Identity of Stenocephalum monticolum (Vernonieae, Asteraceae). Blumea 53: 621-626.

Dematteis M, Pire SM (2008). Pollen morphology of some species of Vernonia s. 1. (Vernonieae, Asteraceae) from Argentina and Paraguay. Grana 47: 117-129.

Di Rienzo JA, Casanoves F, Balzarini MG, González L, Tablada M, Robledo CW (2013) InfoStat versión 2013. Grupo InfoStat, FCA, Universidad Nacional de Córdoba.

Dormer KJ (1961). The crystals in the ovaries of certain Compositae. Ann Bot 25: 241-254.

Erbar C, Leins P (2015). Cuticular patterns on stylar hairs in Asteraceae: a new micromorphological feature. Int J Plant Sci 176: 269-284. 
Erdtman G (1960). The acetolysis method. A revised description. Svensk Botanisk Tidskrift 54: 561-564.

Faust WZ, Jones SB (1973). The systematic value of trichome complements in a North American group of Vernonia (Compositae). Rhodora 75: 517-528.

Foster AS (1955). Plant idioblast: remarkable examples of cell specialization. Protoplasma 46: 184-193.

Freitas FS, De-Paula OC, Nakajima JN, Marzinek J (2015). Fruits of Heterocoma (Vernonieae-Lychnophorinae): taxonomic significance and a new pattern of phytomelanin deposition in Asteraceae. Bot J Linn Soc 179: 255-265.

Haque MZ, Goward MBE (1984). New records of the carpopodium in Compositae and its taxonomic use. Bot J Linn Soc 89: 321340.

Hind DJN (1993). Notes on the Compositae of Bahia, Brazil. Kew Bull 48: 245-277.

Isawumi MA (1999). Floral microcharacters and taxonomy of the tribe Vernonieae: Asteraceae (excluding Vernonia Schreb) in West Africa. Feddes Repertorium 110: 359-374.

Isawumi MA, El-Ghazaly G, Nordenstam B (1996). Pollen morphology, floral microcharacters and taxonomy of the genus Baccharoides Moench (Vernonieae: Asteraceae). Grana 35: 205-230.

Jones SB (1979). Chromosome number of Vernonieae (Compositae). Bulletin of the Torrey Botanical Club 106: 79-84.

Keeley SC, Jones SB (1979) Distribution of the pollen types in Vernonia (Vernonieae: Asteraceae). Syst Bot 4: 195-202.

Keeley SC, Robinson H (2009). Vernonieae. In Funk VA, Susanna A, Stuessy TF, Bayer RJ editors. Systematics, Evolution, and Biogeography of Compositae. Vienna, Austria: International Association of Plant Taxonomy, pp. 439-469.

King RM, Robinson H (1970). The New Synantherology. Taxon 19: 6-11.

Loeuille B, Keeley SC, Pirani JR (2015) Systematics and Evolution of Syncephaly in American Vernonieae (Asteraceae) with Emphasis on the Brazilian Subtribe Lychnophorinae. Syst Bot 40: 286-298.

Mazen AMA, Zhang D, Franceschi VR (2004). Calcium oxalate formation in Lemna minor: physiological and ultrastructural aspects of high capacity calcium sequestration. New Phytol 161: 435-448.

Mendonça CBF, Albuquerque de Souza M, Gonçalves-Esteves V, Esteves RL (2007). Palinotaxonomia de espécies de Chrysolaena H. Rob., Echinocoryne H. Rob. e Stenocephalum Sch. Bip. (Vernonieae-Compositae) ocorrentes no sudeste do Brasil. Acta Botanica Brasilica 21: 627-639.

Metcalfe CR, Chalk L (1979). Anatomy of the Dicotyledons. Vol. I. Oxford, UK: Clarendon Press.

Narayana BM (1979). Taxonomic value of trichomes in Vernonia Schreb. (Asteraceae). P Indian Acad Sci A 88: 347-357.
Punt W, Hoen PP, Blackmore S, Nilsson S, Le Thomas A (2007). Glossary of pollen and spore terminology. Review of Palaeobotany and Palynology 143: 1-81.

Robinson H (1987). Studies of the Lepidpaloa Complex (Vernonieae: Asteraceae). I. The genus Stenocephalum Sch. Bip. Proceedings of the Biological Society of Washington 100: 578-583.

Robinson H (1988). Studies in the Lepidaploa complex (Vernonieae: Asteraceae). IV. The new genus Lessingianthus. Proceedings of the Biological Society of Washington 100: 929-951.

Robinson H (1992). The Asteraceae of the Guianas, III: Vernonieae and restoration of the genus Xiphochaeta. Rhodora 94: 348361.

Robinson H (1999). Generic and subtribal classification of American Vernonieae. Smithsonian Contributions to Botany 89: 1-116.

Robinson H (2009). An introduction to micro-characters of Compositae. In Funk, VA Susanna A, Stuessy TF, Bayer RJ editors. Systematics, Evolution, and Biogeography of Compositae. Vienna, Austria: International Association of Plant Taxonomy, pp. 89-100.

Roque N, Keil DJ, Susanna A (2009). Illustrated glossary of Compositae. In Funk VA, Susanna A, Stuessy TF, Bayer RJ editors. Systematics, Evolution, and Biogeography of Compositae. Vienna, Austria: International Association of Plant Taxonomy, pp. 781-806.

Schultz-Bipontinus CH (1863). Geschichte der Gattung Lychnophora. Pollichia 20: 329-439.

Stix E (1960) Pollen morphologische Untersuchungen an Compositen. Grana 2: 41-104.

Stuessy TF, Sang T, Devore ML (1996). Phylogeny and biogeography of the Barnadesioideae, with implications for early evolution of Compositae. In Hind DJN, Beentje HJ editors. Compositae: Systematics. Proceedings of the International Compositae Conference. Kew, UK: Royal Botanic Gardens, pp 463-490.

Thiers B (2017). onward (continuously updated). Index Herbariorum. New York Botanical Garden. Website http://sciweb.nybg.org/ science2/IndexHerbariorum.asp [accessed 10 August 2017].

Via do Pico GM, Dematteis M (2013). Taxonomic implications from the pollen morphology in the genus Chrysolaena (Vernonieae, Asteraceae). Palynology 37: 177-188.

Via do Pico GM, Vega AJ, Dematteis M (2016). Systematic consideration of floral microcharacters of the South American genus Chrysolaena (Vernonieae, Asteraceae). Systematics and Biodiversity 4: 224-243.

Wagner MA, Loeuille BFP, Siniscalchi CM, Melo-de-Pinna GF, Pirani JR (2014). Diversity of non-glandular trichomes in subtribe Lychnophorinae (Asteraceae: Vernonieae) and taxonomic implications. Plant Syst Evol 300: 1219-1233.

Zarlavsky GE (2014). Histología Vegetal: técnicas simples y complejas. Buenos Aires, Argentina: Sociedad Argentina de Botánica. 


\section{Appendix. Specimens analyzed}

Stenocephalum apiculatum (Mart. ex DC.) Sch.Bip.

Bolivia, Santa Cruz: Fortin Ravelo, Cerro San Miguel, III.1989, Mereles 2742 (CTES), Chiquitos, $18 \mathrm{~km}$ from Roboré on road to Santiago de Chiquitos, 11.IV.1998, Wood and Mamani 13477 (K). Brazil, Bahia: Abaíra, Boa Vista, 5.V.1992, Ganev 251 (CTES).

S. hexanthum var. hexanthum Sch.Bip.

Argentina, Corrientes: Capital, Riachuelo, 10.I.1976, Schinini and Ahumada 12403 (CTES). Brazil, Mato Grosso: Dourados, 22.X.2003, Hatschbach et al., 76622 (CTES). Paraguay, Amambay: Chirigüelo, 14.XII.1999, Dematteis et al., 887 (CTES).

S. hystrix (Chodat) H.Rob.

Brazil, Mato Grosso do Sul: Campo Grande, road to Sidrolandia, 10.II.1979, Krapovickas and Cristóbal 34511 (CTES). Paraguay, Natural Reserve Mbaracayú: AguaráÑú, 210 msm, 7.XII.2003, Múlgura de Romero et al., 3590 (CTES); Canindeyú: Aquere-mí, in cerrado, XI.1995, Basualdo 5948 (FCQ); 25 km E of Igatimí, 5.XII.1998, Dematteis and Schinini 852 (CTES).

S. jucundum (Gleason) H.Rob.

Mexico, Chiapas: Tomalá, Iglesia Vieja, 24.X.2002, Alvarado and Reyes 729 (MBM); Oaxaca: $8 \mathrm{~km}$ to $\mathrm{S}$ of Matías Romero, 21.XI.1984, Tellez et al., 8186 (CTES).
S. megapotamicum (Spreng.) Sch.Bip.

Argentina, Corrientes: Santo Tomé, Garruchos, 12.II.1960, Pedersen 5413 (CTES); Misiones: Concepcion, 14.XII.2007, Zuloaga 9839 (CTES). Brazil, Rio Grande do Sul: $25 \mathrm{~km} \mathrm{~S}$ of Vacaría, BR-116, 14.X.1980, Krapovickas et al., 23015 (CTES). Uruguay, Montevideo: Montevideo, Sellow s. n. (BR, W).

S. monticola (Mart. ex DC.) Sch.Bip.

Brazil, Bahia: Abaira, Ägua Limpa, Morro do Cuscuzeiro, 29.V.1994, Ganev 3180 (HUEFS); Abaira, Salão, Campos Gerais do Salão, 2.V.1994, Ganev 3192 (HUEFS); Barra da Estiva, Barra da Estiva-Ituaçu, 18.V.1999, Souza et al., 22666 (ESA). Minas Gerais: Santo Tomé das Letras, 22.III.1987, Hatschbach et al., 51220 (MBM).

S. tragiaefolium (DC.) Sch.Bip.

Brasil, Minas Gerais: Poços de Caldas, Campo do Saco, 23.XI.1988, Motta 1580 (CTES); Paraná: Palmeira, 55 km of Ponta Grossa, next to Rio dos Papagaios, 15.II.2006, Souza et al., 32076 (ESA); Sao Pablo: Brooklin Paulista, 30.IX.1948, Hoehne 2736 (CTES).

V. hexantha var. nivea Chodat

Paraguay, Cordillera: Emboscada, Schinini and Barrail 31768 (CTES), Misiones: Santiago, Estancia La Soledad, 16.XII.1969, Pedersen 9591 (CTES); Paraguarí: Caapucú, 12.XII.1969, Pedersen 9537 (CTES). 